DOI: 10.20472/IAC.2018.040.009

\author{
ANGEL CALVO \\ University of Barcelona, Spain
}

\title{
BUSINESS AND ECONOMICS IN THE COLD WAR: AN APPROACH FROM A NON-CORE COUNTRY (SPAIN)
}

\begin{abstract}
:
The imposition of political motives on far-reaching economic decisions has been at the center of international debate for many years, especially during the Cold War. Frequent attacks of international terrorism have brought to the foreground the paramount importance of international security and policies that are conducive to it. This paper aims to deepen the understanding of the functioning of some features of the world economy during the Cold War. It analyzes the scope of policies to control the transfer of Western advanced technology to enemy countries in the framework of a division of the world into blocks. In particular, it is proposed to examine the mechanisms of the technological embargo imposed by the hegemonic power in the West -USA- and its economic impact on several Spanish companies of the high-end sectors. This contribution adopts an interdisciplinary perspective that combines the economic approach of Adler-Karlsson (1968), the most general of the geo-economics and the business of Segreto (2006). The work lies on an updated bibliography and incorporates new primary sources, including business and USA governmental documents.
\end{abstract}

\section{Keywords:}

Cold War, Transfer of technology, entrepreneurship, CoCom, exports control. 